\title{
Summaries of articles
}

\author{
Climatic variations in the Middle Ages (Belgium, \\ Rheinland, the North of Francel
}

Pierre Alexandre

The historian has an important contribution to make to knowledge of the climatic variations of the past: the written, narrative sources of the Middle Ages (annals, chronicles, etc.) contain a large number of meteorological observations; by using various calculation processes one can obtain from these data (which are essentially qualitative) curves showing the evolution of the climate.

This article considers the area made up of Belgium, Rheinland and the North of France during the period 1100-1400. The meteorological observations contained in chronicles from this area and this period provide information for two graphs: the first recording changes in winter temperatures, the second changes in precipitation levels in summer. The quantification process used here deals in ten-year periods, following the system established by English meteorologist H. H. Lamb. The graphs obtained here for Belgium agree with those plotted by Lamb for England: a warming of the atmosphere in the second half of the twelfth century and in the thirteenth, then cooling in the fourteenth century-a foretaste of the "little ice age" of the modern era. Until a similar study has been carried out on a European scale however these conclusions must be considered hypothetical.

\section{Climate history and the economy: new evidence and new interpretations}

Jan DE VRIES

The new evidence presented and analysed in this article represents the annual number of days a Dutch canal was closed by ice in the period 1634-1839. Correlation and regression analysis were used to estimate average winter temperatures. The same techniques were applied to French wine harvest dates to create a companion series of summer temperatures, but the results uncovered important weaknesses in this source which receive detailed analysis.

The resulting long series of winter temperatures is analysed statistically to identify possible long cycles. The conclusion is that periods of maritime and continental climate alternated, and that these periods have been from 60 to 100 years duration. The "little ice age" concept is examined in the light of these findings.

Finally, the effect to annual changes in winter temperatures on six Dutch economic variables is analysed. Various methods are employed but the results are essentially 
negative. The effect of climate on the economy is real but subtle; the crude historical indicators of climate at our disposal do not suffice to identify the economic impact of annual weather fluctuations.

\section{Climatic fluctuation:}

a synoptic study (1781-1820)

John KINGTON

The present article reviews a research project concerning the construction and analysis of historical daily synoptic weather maps from 1781. The 1780's were selected as a starting point both because adequate sources of data existed from that time on and because climatic conditions during this period were distinctly different from those of 1900-1939.

After a brief discussion of the development of instrumental meteorological observing over the past three centuries, a comparative investigation is undertaken between the 40-year climatic period 1781-1820 and the "normal" datum 1900-1939. The Lamb British Isles weather types and circulation patterns are applied to selected 4-year phases. The data are presented in tables of yearly and average frequencies of weather types and tables of the central England temperature series.

Further synoptic climatological studies are suggested, including investigation of large-scale circulation patterns and construction of 500 millibar charts.

\section{Dendrochronology and fossil wood: an attempt at dating by heteroconnection}

Pierre DE MARTIN

In principle, dendrochronology disapproves of heteroconnection, that is, the comparison of age-rings of different species for the purpose of dating. It seems, however, that there exist extraordinary periods of vegetation whose strong climatic traits produce an effect, be it favorable or unfavorable, which is identical for the age-rings of all species. Identification of these "equalconsequent" years has made it possible to date a sample of cembra pine from the Grindelwald glacial moraine by referring to the chronology of Ernst Hollstein's oaks from west of the Rhine. This dating seems indisputable, having been also confirmed by the radio-carbon method. Heteroconnection is thus possible if certain conditions are respected. It is necessary to remain within a given climatic region, work with a sample of at least 200 age-rings, and make sure the data include at least $20 \%$ equalconsequent years.

\section{Literature and politics: \\ writers and the Dreyfus case}

Christophe Charle

To understand the political engagements of writers in the Dreyfus case, one must consider their situation in the existing fields of literature and politics. The "dominated" pole of the literary camp (the poetic avant-garde) was mainly pro-Dreyfus. The dominant pole, on the other hand, which was composed of the French Academy and the writers who surrounded it, was anti-Dreyfus. The middle sector (novelists and those who wrote for the boulevard theater) was equally divided, the naturalist movement for example. Knowledge of the political roles played by these different groups is essential to the understanding of their choices.

The avant-garde initiated the struggle in order to assert the purist values which it 
upheld in literature. The Academy, on the other hand, reacted in order to protect the traditional cultural order. Those who were rejected by the dominant pole used their audience in the political arena to launch the "affaire", Zola, for example. Those who would approach the dominant pole remained neutral or were anti-Dreyfus. On the whole, the case shows that intellectuals were dominated in the political arena and could not, in the end, come to a decision. The social position of intellectuals in France is linked to the growth of their numbers and this is important, for the more numerous they are, the less they can decide.

\section{Le Monument Henry}

Stephen WILSON

The Henry Subscription provides a rare insight into the structure and function of antisemitism at the popular level, in France in the 1890's and generally. The paper first analyses the geographical distribution of subscribers, finding that their incidence was high in the East and the South-East in particular, for very different reasons, and that they came predominantly from cities and small towns. The break-down of subscribers by profession, which follows, indicates a high incidence among the military and the Catholic clergy, but also among workers and artisans, students and the liberal professions. Surprisingly, incidence was low among white-collar workers, and average among small traders. Finally, analysis of the messages accompanying subscriptions suggests that antisemitism had a powerful explanatory as well as compensatory function in circumstances of rapid social change. In the face of change it affirmed a set of $a b$ solute values in opposition to the Jew, who was characterised very particularly as a polluting agent. As such he had to be eliminated from the city, though such elimination was envisaged in symbolic and not actual terms.

\section{The Ashanti in the nineteenth century}

Emmanuel Terray

Ivor Wilks' book marks an essential stage in the development of historical research on pre-colonial Africa. By the wealth and diversity of his sources, Ivor Wilks renews completely our knowledge of Ashanti history for the eighteenth and nineteenth centuries: far from being entirely dictated to by its relations with Europe, the Ashanti kingdom is a crossroads, widely exposed to Sudanese influences, and knows how to play upon its position to ensure its independence and prosperity. Ivor Wilks presents successively the evolution of the monarchy and its gradual "secularisation"; the transformation of institutions and the halting progress of centralization; the movement of factions within the reigning elite, and what was at stake in their conflicts; and finally, the process of the emergence of social classes beginning in the second half of the nineteenth century. He thus reconstructs a history of the Ashanti as seen from within, in which are restored to their rightful places beside the analysis of causes, the analyses of motives, projects and ideologies.

\section{The chronology of oral tradition}

\section{Claude-Hélène PERrot Emmanuel Terray}

The work of D.P. Henige proposes to show that oral tradition is of no help in that fundamental operation of historical research, the establishment of chronology. Henige illustrates his proposition with examples borrowed notably from Ashanti history. But a 


\section{SUMMARIES OF ARTICLES}

careful study of these examples reveals that they in no way say what Henige would have them say, and the arguments that he deduces from them are proof of a certain lack of understanding on his part of the actual conditions in which the collection of oral traditions takes place. In reality, these traditions are historical documents like any others; they must be subjected to a critical evaluation which takes account of their particular nature, but they also quite often contain in themselves the indications which make it possible to rectify or complete their statements. Oral and written sources are complementary, but not of equal value: the latter make it possible to raise questions that were not encountered in the oral investigation, but the oral sources alone can supply meaningful answers.

\section{Annexing the carnaval: \\ analysis of a 17 th-century Roman féte}

Martine BoITEux

Without attempting a global interpretation of the Roman carnaval, the author uses a specific example, the comparison of the Giostra and Gazzarra to isolate various salient elements of carnaval language. Although these belong to different registers, the information they provide about each other makes it possible for them to be considered as a homogeneous whole. Based on divers types of information, both written and iconographic, the analysis is conducted in three successive stages: an esthetic study of forms, a study of the factors responsible for the phenomena and finally the explicit and implicit values communicated by this official public fete which merged with the ritual of the carnaval and annexed it. How did the reigning Barberini family, through use of symbols taken over and revitalized by the 1634 Giostra del Saraceno, annex the festive virulence of the carnaval and impose their own political system and a socio-cultural model? By the use of ethnological methods, the author is able to shed some light on the carnaval ritual and the way it functioned in Roman society at the beginning of the 17th century.

\section{"Charivari":}

popular custom and the bourgeoisie
Rolande Bonnain-MoERdick Donald MOERDICK

Using as the basis of our work a file on "charivari" which was compiled by the prefecture of the Hautes-Pyrénées during the first half of the last century, we propose to clarify the relationship between village customs and those who follow them. Charivari have been studied in France principally in relation to marriage economy. The present documentation allows us to go beyond this framework and examine the relationships between the peasants and the bourgeoisie within the power structure of the village communities, at a time when this folkloric activity was used on a nation-wide scale as a means of expressing opposition to the Régime. In an appendix, we shall see how the "coutume de la ronce" loses its meaning, retaining only its symbolic representation, money. 